811.163.41'373.7

821.163.41.08 Петровић Његош П. II https://doi.org/10.18485/sj.2020.25.1.7

РАДМИЛО Н. МАРОЈЕВИЪ ${ }^{*}$

Универзитет у Београду

Филолошки факултет
Оригинални научни рад

Примљен: 15. 10. 2019.

Прихваћен: 15. 01. 2020.

\title{
ФРАЗЕОЛОШКИ ЖАНРОВИ У ШЋЕПАНУ МАЛОМ
}

У овом раду** се разматра класификација фразеолошких жанрова у Његошевом спјеву Шћепан Мали. Стални епитети (1), устаљена поређења (2) и идиоми (3) чине групу синтагматских фразеологизама. - У реченичне фразеологизме убрајају се пословице (4), изреке (5) и (вјерске) узречице (6). - Трећи дио рада посвећен је оптативним фразеологизмима, а то су заклетве (7), клетве, благослови, опраштања, добродошлице и здравице (8), апотеозе и благодарења (9), квалификативи (10) - упитаности, благе вијести, невоље и жалости. - Хендиадис (11), перифраза (12), таутолошки изрази (13) и суперлативни изрази (14) издвајају се у групу фразеолошких стилских фигура.

Кључне ријечи: Петар II Петровић-Његош, спјев Шћепан Мали, синтагматски фразеологизми, реченички фразеологизми, оптативни фразеологизми, фразеолошке стилске фигуре

0.1. Специфичност фразеолошког језичког слоја представља трећи круг питања која се тичу семантичке реконструкције текста у Његошевом спјеву Шћепан Мали. Тај језички слој на граници је лексике, односно лексичке реконструкције, и синтагматике, односно граматичке реконструкције.

0.2. Подјелу фразеолошког слоја језика на фразеолошке жанрове, на грађи Горског вијенца, направила је Ана Пејановић у монографији Фразеологија

*radmilo@mail.ru

** Из пројекта „Пјесничка дјела Петра ІІ Петровића Његоша у оригиналу и руским преводима”, Института за славистику и филологију Паневропског универзитета Апеирон у Бањој Луци. 
Горског вијенца: Фразеолошки жанрови. Културни концепти. Руски преводи [ПЕЈАнови и 2010]. На тај начин је превазиђена дилема о опсегу фразеолошког слоја језика, као и дискусија о фразеологизмима у ширем и ужем смислу. Аутор издваја осам фразеолошких жанрова.

0.3. Жанровска структура Шћепана Малог, међутим, много је разуђенија и богатија, што ће се одразити и на нашу класификацију фразеолошких жанрова.

0.4. Овдје доносимо преглед фразеологизама, подијељених на фразеолошке жанрове, а потпунију анализу остављамо за планирани Лексикон Његошевих дјела (Том II: Шћепан Мали).

\section{1. СИНТАГМАТСКИ ФРАЗЕОЛОГИЗМИ}

1.1. У прву групу (синтагматски фразеологизми) сврстали смо праве фразеологизме - сталне епитете, устаљена поређења и идиоме.

Фразеолошки жанр 1. С т а л н и е п и т е т и (по класификацији Ане Пејановић) [ПЕЈАнови 2010: 10-29] у Шћепану Малом најчешће је фолклорног поријекла. Треба имати у виду да стални епитет као фразеолошки жанр чине и придјев, који се у извјесном смислу десемантизује, и именица, која чува пуноћу свога значења.

(1) Основни облик сталног епитета у народном језику јесте синтагма именице с односним придјевом, на примјер: нѐк' у̀стаје нӓ ноге ла̀га̄не̄, [ШМ 794], или с описним придјевом одређеног вида, на примјер: од вр̈[х] главе до зѐлене̄ траве. [ШМ 977].

(2) Стални епитет се актуализује ако се употријеби облик неодређеног вида, на примјер: с Чева ра́вна и с зелѐна Ви́ра. [ШМ 929].

(3) У неким примјерима придјев има самостално значење, тј. није у саставу сталног епитета. На примјер, од два придјева уз именицу (ак.) Зету у стиховима: у широку Зету увалили - / сву су равну Зету похарали, [ШМ 2077-2078] стални епитет је само синтагма с придјевским обликом равну, у 2078. стиху, док се изразом широка Зета, у 2077. стиху, назива доњи дио некада јединствене области, од уливања Мораче у Зету па до Блата, тј. до Скадарског језера. У савременом језику перцепција је промијењена: заједнички ток се зове Морача, а Зета земља је само с лијеве стране заједничког тока.

1.2. Фразеолошки жанр 2. Ус т а љен а поређењ а [ПЕлАнови 2010 : 29-37], који у другој монографији Ана Пејановић назива компаративним фразеологизмима [ПЕЈАнови 2015], такође се везује за народну традицију. Разврстаћемо их према поредбеном везнику. 
(1) Основни везник је, као и у књижевном језику, ка̀ō, на примјер: Господине, као трн ӱ око: [ШМ 3112].

(2) Дијалекатски везник је кӓко, на примјер: како да си разреза јабуку, / како што су двије капље воде; [ШМ 89-90]. Примјер показује да се поредбени везник често надопуњује везницима $\partial а$ или што, који уводе реченичку структуру.

(3) Сажета варијанта и једног и другог поредбеног везника је ка̂, на примјер: ка̂ миш мали пред добријем мачком! [ШМ 3408].

(4) У неким примјерима устаљена поређења пјесник модификује према контексту, тако да она спадају у пјесникове оказионализме (индивидуална творба): којему су очи ка̂ два сунца [ШМ 1637]; на три старца те су ка̂ три овце? [ШМ 1682]. У овом посљедњем примјеру модификован је фразеологизам (сијед) као овия.

(5) Поређење се може исказати другим средствима, на примјер конструкцијом с компаративом: он се мањи и од мрава чини, [ШМ 1997].

(6) Најзад, треба обратити пажњу на примјере у којима није посвједочено устаљено поређење, на примјер у стиху: шћела би се како стрӱка карта. [ШМ 2094] - јунак хоће да каже да би требало, како би се све описало, имати папир велики као огртач који су некад носили Црногорци.

1.3. Основни тип фразеолошких израза јесу фразеологизми у ужем смислу, а то су 3. Ид и о м и [ПЕЈАнови и 2010: 37-83]. То је најкомплекснији фразеолошки жанр. По поријеклу су различити.

(1) Бројни идиоми су истовјетни као народни, на примјер пљунути на образ у значењу ‘осрамотити’: ёре смо йм на образ пљунули, [ШМ 1300]. У изразу је одражен етнокултурни концепт о браз.

(2) Неки су архаични, на примјер забушити листом у значењу 'све ућуткати': изненада на̂с забуши листом - [ШМ 134].

(3) Да се може и појединачна ријеч (и предлошко-падежна веза) фразеологизовати, показује примјер: кад су на̀ ва̄с Турци и Млечићи - [ШМ 1594], у ком израз на̀ в흐 c $\bar{y}$ значи 'напали су вас'. Чувена порука староруског кнеза Свјатослава Хазарима $и \partial \dot{y}$ на ви́ такође је постала идиом.

(4) Друге идиоме пјесник је модификовао како би им унио неку нову нијансу значења или их укључио у контекст. Тако је, умјесто идиома коса би ти се дигла на глави, употријебљен израз: бй ти коса навише порасла. [ШМ 1567].

(5) Поједине идиоме пјесник је етимологизовао и проширио користећи фразеолошку игру ријечи, на примјер израз скувати (коме) попару добио је два актуализована проширења: стра̂шна̄ ти се скувала попара - / Млетке су је добро осолиле / а Цариград бӧљӗ опаприо: [ШМ 570-572]. 
(6) Идиоми могу бити и индивидуални - то су фразеолошки оказионализми, тј. форме које је пјесник сам створио по обрасцу народних, на примјер очи извадити у значењу ‘заслијепити’, у 2772. стиху: Ку̀ра̄н йм је очи извадио,/ Ку̀ра̄н йм је образ оцрнио, [ШМ 2772-2773]. У 2773. стиху је употријебљен народни идиом у ком је одражен етнокултурни концепт о б р а 3, синонимичан са оним који смо навели [види горе т. (1)], али треба имати у виду да Његош, односно његов лик, овим не окривљује главну исламску вјерску књигу него етничку особину Срба, који, примивши другу вјеру, заборављају име и част народну.

\section{2. РЕЧЕНИЧНИ ФРАЗЕОЛОГИЗМИ}

2.1. У другу групу укључујемо фразеологизме који се остварују на нивоу реченице, фразеологизме у ширем смислу, а то су пословице, изреке и (вјерске) узречице.

Фразеолошки жанр 4. По сл о в и це [ПЕлАнови $2010: 83-90]$ у Шћепану Малом различитог је поријекла.

(1) Неке су истовјетне као народне, тј. фолклорног су поријекла, на примјер: Рӓзвеза је боља слабе свезе: [ШМ 3325]. Јевто Миловић је у свом издању успостављао интертекстуалне везе с Вуковим зборником пословица.

(2) Тешко је доказати фразеолошке оказионализме, тј. форме које је пјесник сам створио по обрасцу народних. То се може основано претпоставити за наредне стихове, с обзиром на генезу стиха у пјесничкој лабораторији Његошевој: ко посрне, мудро̀ват му бране! [ШМ 25] и на контекстуалну условљеност: Ко шубару носити не може, / њему ништа круна не требује. [ШМ 1989-1990].

(3) Поједине пословице пјесник је модификовао како би им унио неку нову нијансу значења, укључио их у контекст или у силабичку структуру стиха, као у примјеру из 2527. стиха: Своје с ту́ђйм није смијешано - / од ту́ђе̄га свагда туга бије. [ШМ 2526-2527]. За први од наведених стихова претпостављамо да је фразеолошки оказионализам.

2.2. Фразеолошки жанр 5. Из р еке [ПЕЈАнови и 2010: 90-94] одражава културни код једног етноса или његове уже заједнице. Изреке су, у принципу, разумљиве сваком припаднику те заједнице, односно изворном говорнику (носиоцу језика), у одговарајућој историјској епохи, тако да коментар изискују прије свега изреке које имају интеркултурални контекст.

(1) Изрека може припадати широј културној традицији, укључујући античку. Лазо М. Костић (у чланку Порекло једног стиха из Шћепана Малог 
у зборнику „Његош и антика”) указује на једну такву паралелу, па доводи у везу 2880. стих Шћепана Малог:

Народ крсти како ко́га хоће ко ће порећ бо̀ж’јȳ и на́родњӯ?

[ШМ 2879-2880]

с латинском изреком: Vox populi, vox Dei, која значи: Глас народа, то је глас Бога [Костић Л. 2000: 447].

(2) У истом зборнику, али у чланку Једно античко правно начело у Шћепану Малом, којим се зборник завршава, Лазо М. Костић наводи стихове 1152-1154 (којима ћемо ми додати и претходни, 1151. стих):

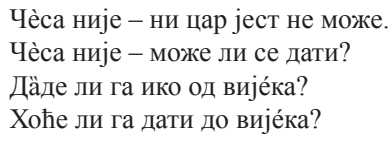

[ШM 1151-1154],

а затим и стих:

Како ће се дати чѐса није?

[ШM 1187],

и у њима налази одражену максиму из римског права, која на латинском гласи: Dare nemo potest quod non habet, nec plus quam habet, а у преводу: Нико не може дати оно што нема, нити више него што има. Аутор чланак (и зборник „Његош и антика” у цјелини) завршава констатацијом: „Његош је јамачно нашао и ову врсту говора код народа, само јој је дао песнички облик својствен њему, јасноћу и простоту која чак и латински текст засењује" [Костић Л. 2000: 452].

Народни карактер израза нарочито потврђује стих који је Костић пропустио да наведе, а којим је пјесник латинско-српску паралелу новом изреком повезао с контекстом (Теодосија Мркојевић алудира на султана Мустафу који тражи да „поједе” Шћепана Малог).

(3) Изреке често одражавају поглед на свијет епохе, на примјер: не бојим се до Бога никога. [ШМ 2898] или историјску ситуацију, на примјер: Смијешна је вјера у јачега: [ШМ 1412] (придјев смијешан је семантички дијалектизам у значењу 'чудан').

(4) Неке изреке у десетерачкој форми изражене у Шћепану Малом постале су Његошеве кр и л а т ц е: Није стйдно похвалит се прӓво: [ШМ 450]; Ко вјечито хоће да живује / мученик је овога свијета. [ШМ 1822-1823].

2.3. Посебно ћемо издвојити изреке с мимичко-гестовном потпором, које захтијевају двоструки коментар - коментар геста и коментар текста. 
(1) Ако је изрека праћена неким гестом, онда је потребно указати и на тај гест, односно на ванјезичку ситуацију, као у примјеру из 3181. стиха:

Ко је да̀ је (ја га не позна̀јем):
о њему се за ово питало,
ал га народ за цара др̈жа̄ше,
че̂ствова̄ше и бојаше га се,
и народ се овијем именом
окреташе како желијасмо,
како свијет около пјанога -
њим дража̄смо слогу у народу.

[ШM 3180-3187].

У оваквој ситуацији говорник чини гест палцем десне руке (лијеве ако је љевак) примичући га горњим зубима или покаже на нокат. Умјесто за ово говори се и за ирно испод нок(а)та.

Као интертекстуалну паралелу, у којој је израз и објашњен, наводимо примјер из приповијетке „Ветар” Лазе К. Лазаревића: Јоца, познатим маневром, запевши нокат од палца за секутић и одапевши, даде ми знати: „Хич!” [ЛАзАРеви 2011: 186]. Овај примјер је навела Драгана Вељковић-Станковић у раду Мимичко-гестовна потпора дијалога у приповеткама Лазе К. Лазаревића (на 49. Научном састанку слависта у Вукове дане, 13. септембра 2019), од које смо преузели и терминолошку ознаку.

У Речнику Његошева језика примјер се не наводи и не коментарише, ни у глаголској, ни у замјеничкој одредници, ни у одредницама предлошким (по принципу: што је састављачима нејасно, то се искључује из лексикографске обраде). Поред геста, требало је објаснити и текст - о њему се питало значи 'он се (не) питао'; супстантивизирана пак показна замјеница ово не односи се на 'нокат', како би неко могао помислити на основу интерконтекстуалне потврде, него на - 'црно испод нокта'.

(2) И неке друге изреке алудирају на гест као пратећу појаву: све би пӧја̄ и увис скакао - [ШМ 2068]; бацам капу увис к небесима, [ШМ 1738]. У овим стиховима одражен је гест исказивања радости и весеља у националној култури, тј. у Црној Гори тога времена.

У стиху: баш нам капе лете око главе: [ШМ 3410] одражен је гест исказивања забринутости у турском табору, чију је гестовну природу покушао да објасни Драгутин Костић: „Како су забринути једнако се чешу по глави, те помичу капу овамо онамо" [Костић Д. 1902: 185 (нап.)], и успјешно је то учинио. У Речнику Његошева језика у одредници каัпа наводи се израз „ н нам лети око главе имамо много брига; у великој смо невољи, неприлици" [СтевАновић и др. 1983 I: 340]; семантизација је тачна, али се не види зашто се тако каже. 
(3) Гестовну подлогу има израз накривити капу у 655. стиху: здраво ћу те кући отправити, / под оेрӱж’јем, капе накривљене. [ШМ 654-655]. У Речнику Његошева језика не наводи се глагол накри́вити као одредница, ни трпни придјев тога глагола, него се само, у одредници кӓпа, објашњава израз „накри иљене капе безбрижно, не марећи ни за шта” [СтевАновић и др. 1983 I: 340]. Семантизација није адекватна: израз (можеш) накривити капу значи ‘(можеш бити) потпуно задовољан' (односи се на оно што је било, а не на оно што ће бити). Фразеологизам одражава обичај да мушкарац, кад је весео и задовољан, накриви капу (фес се није могао накривити).

(4) Први полустих 3213. стиха:

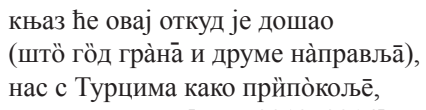

указује на пратећи гест, што је лексички изражено, и на основну радњу (приิча̂), што није лексички изражено, тако да он значи 'ма колико да прича гестикулирајући рукама (ради веће убједљивости)'. У Речнику Његошева језика семантизује се и глагол и израз: „гра̀нати, -а̄м несврш. изражавати радост; у изр. и друме направ љати обећавати златна брда, улепшавати, дотеривати у причању" [С тевАнов и и и др. 1983 I: 131]. Сам глагол, тј. ван контекста, значи ‘гестикулирати (у причању)' без обавезне семе радости. То је једно.

Друго. Два предиката немају једно јединствено значење, него два (не представљају хендиадис као стилску фигуру). У другом полустиху израз заиста значи 'обећавати златна брда и долине' (не знамо зашто су лексикографи заборавили долине кад већ фразеологизам објашњавају фразеологизмом), с тим што глагол направљати нема руско 'усмјеравати’ него српско дијалекатско значење 'правити, израђивати'. И лексикографи га тако тумаче, али му опет прикључују два израза умјесто један: „Изр. гранати и друме $~ 6$. гранати (изр.)" [СтевАновић и др. 1983 I: 488, s. v. на̀прављати].

И треће. Једино што у нашем тумачењу може бити дискутабилно јесте одјељак у који смо примјер укључили - једна ријеч, по некима, не може бити фразеологизам. Супротно мишљење могло би се бранити другим дијелом наслова Народне српске пословице (у другом и дефинитивном издању: $C p$ пске народне пословице) Вука Кара̀џића: ...и оне као у обичај узете ријечи [КАРАџИ 1836; КАРАџИЋ 1849].

2.4. Фразеолошки жанр који Ана Пејановић у Горском вијениу издваја као 6. Уз речице [ПелАновић 2010: 107-122] у Шћепану Малом је веома разноврстан. Ми у узречице убрајамо прије свега изразе који имају или могу имати реченичку структуру одражавајући цјеловиту мисао. 
(1) Нӓјчешће̄ су узречице у којима се помиње (хришћански) Бог, на примјер: Опрости ми Боже свемогући: [ШМ 547]. У ову групу узречица укључујемо оне изразе које користе Црногорци као хришћани (у том периоду сви су православци).

(2) Муслимани у спјеву не користе словенску именицу Бог, рану позајмицу из индоиранске групе индоевропских језика, него арапску Ӓллй (опонашајући и њен изговор): са пӧмоћо̄м турскога Ӓлла̄ха, [ШМ 1363] (може бацит свијет да му прсне). Ту именицу у арапској култури користе и припадници хришћанства и јудаизма. У ову групу узречица укључујемо оне изразе које употребљавају муслимани у турском табору.

(3) У трећу групу узречица убрајамо оне које одражавају стари, још пагански систем вјеровања, без обзира на то да ли се изговарају у црногорском: Јад их знао у̀ њихову главу. [ШМ 628] или у турском табору: са онијем вра́жијем ми́летом: [ШМ 3728].

\section{3. ОПТАТИВНИ ФРАЗЕОЛОГИЗМИ}

3.1. У трећу групу фразеологизама спадају они изрази који су, на овај или онај начин, генетски везани за некадашњи императив трећег лица једнине у оптативном значењу.

Фразеолошки жанр из Горског вијениа 7. 3 ак л е т в е [ПЕЈанови 2010: 101-107] у Шћепану Малом је представљен изразима различите формалне структуре.

(1) У овом жанру употребљава се, прије свега, предикатив тӓко (ти Бӧга), који има побочни краткосилазни акценат, па с обликом генитива именице с главним акцентом формира сложену фонетску ријеч: Хоћу, Ба̂jo, тӓко ми Про̀рока [ШМ 687]; Није, кнеже, тӓко ми Кура́на, [ШМ 1136]; Ја се чудим, тӓко ми ћита́па, [ШМ 1394]; али нѐj’ма̄, тӓко ми муса́фа, / калуђера ка̂ тебе безбожна. [ШМ 1451-1452]; Ја се чудим, тӓко ми сеџа́де̄, [ШМ 3547].

Предикатив се прозодијски разликује од хомонимичног замјеничког прилога, која има главни, краткоузлазни акценат на првом и дужину на другом слогу, а употребљава се у адвербијалној функцији: По̀ чем та̀ко̄ ти познаде чисто / цара главом у̀ тога̄ чӧвјека? [ШМ 43-44] и у саставу предиката: То је та̀ко̄? Што ми већ за̀меће̄ш? [ШМ 1192]. У два сусједна стиха употријебљени су ови лексичко-граматички хомоними - у 1407. стиху предикатив, а у 1408. прилог: Де тӓко ти тво̀је̄ црне вјере, / ништа немој околишат та̀ко̄, [ШМ 1407-1408].

О предикативима као иновацији у систему врста ријечи види у МАРоJEвић 2020: 626-627. 
(2) Предикатив тӓко као компонента фразеолошке структуре може бити елидиран, као у примјеру: а Бога ти: куд ће већи ѝзгуб? [ШМ 3192]. Занимљиво је да исту конструкцију користе и православни: мишљах чисто, бабове ми душе, [ШМ 1788] и исламизирани Срби: да устану, бабове ми душе, [ШМ 3606] (именица бабо је иначе турцизам).

(3) У фразеолошком жанру заклетве посвједочен је оптатив с негацијом (не судио) у коме није могуће васпоставити глаголску копулу, тј. умјесто не употријебити [није]:

$$
\begin{aligned}
& \text { Ја нијесам (Бог ми не судио!), } \\
& \text { бѐглер-бёже, нипошто безбожан, } \\
& \text { [ШМ 1453-1454]; } \\
& \text { Рад нијесам (Бог ми не судио!) } \\
& \text { да на мене што̀год старац суิмја̄ } \\
& \text { злобе сјёме да у срцу носим. }
\end{aligned}
$$

[ШМ 1974-1976].

3.2. У фразеологији Горског вијениа Ана Пејановић издваја жанр 8. Клетв е [ПЕЈАнови ъ 2010: 94-101]. Ми клетве посматрамо у низу с фразеологизмима с другим значењима (благослова, добродошлице, опраштања и др.) као јединствени фразеолошки жанр. Да је то јединствен фразеолошки жанр показује примјер: Никад нам се бољи не родио: [ШМ 1980] - формално је то клетва, али у контексту реплике прикључује се жанровима са супротним предзнаком.

Сви се ти подтипови овог фразеолошког жанра изражавају оптативима као једном од двије нове врсте ријечи у српском језику. Они су настали трансформацијом радних глаголских придјева (губљењем категорије падежа и синтаксичке категорије лица). О оптативима као иновацији у систему врста ријечи види у МАРолевић 2020: 626.

(1) Клетв е као подтип овог фразеолошког жанра у Шћепану Малом имају различиту формалну структуру.

$1^{\circ}$ Најчешће се исказују оптативом у потврдној: Ал Млечићи (црн им образ био!) [ШМ 767]; Бог ти мајку убио опаку! [ШМ 1877] или одричној форми: не родила ка̀вӯрка таквога! [ШМ 1058].

$2^{\circ}$ Клетва се може трансформисати у узречицу: Јад их знао у̀ њихову главу. [ШМ 628].

$3^{\circ}$ Оптатив у клетви може бити изостављен: Тӓмерла̄не, душа ти про̀кле̄та [ШМ 1059].

$4^{\circ}$ Клетва може бити исказана новим, описним императивом трећег лица једнине: О нѐсрећо да те Бог убије, [ШМ 40]. 
(2) Бл а го с л о в и као подтип овог фразеолошког жанра, са супротним од клетви предзнаком, такође могу имати различиту формалну структуру.

$1^{\circ}$ Најчешће се и они исказују оптативом, као у примјерима: Камо Шћепан да се пољубимо - / па га ето, и честит ви био! [ШМ 2025-2026]; Ха̀йрли нам твој долазак био! [ШМ 3699] (ха̀ирли је турцизам у значењу 'срећан’).

$2^{\circ}$ Благослов је могао бити исказан старим императивом трећег лица једнине, али је он преображен у поздрав: Помо̀зи Боิг, јуначки народе, [ШМ 1846].

$3^{\circ}$ Благослов може бити исказан новијим, описним императивом трећег лица једнине с везником $\partial a$ (види други стих у наредном примјеру).

$4^{\circ}$ Благослов може бити исказан и најновијим, описним императивом трећег лица једнине с везником нека, као у 1957. стиху: нѐк ви слӓва иде по свије́ту / й да ви се до пӧслијед прича! [ШМ 1957-1958].

(3) Фразеолошки подтип оп раш та њ а може имати различиту формалну структуру.

$1^{\circ}$ У примјеру: прӧста би́ла Сата̀нину роду / ћуд опака под црүно̄м хаљином! [ШМ 765-766] фразеологизам је у форми личне реченице.

$2^{\circ}$ У примјеру: Бӧгом прӧста моја стра̀да̄нија, [ШМ 454] фразеологизам је такође употријебљен у личној реченици, али је у њој елидиран сам оптатив [би́ла].

$3^{\circ}$ У сљедећем контексту:

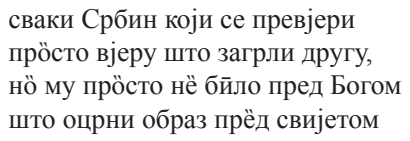

[ШМ 2815-2818]

фразеологизам је употријебљен у безличној реченици, при чему је у 2816. стиху елидиран оптатив, али се он лако васпоставља према 2817. стиху: прӧсто [му би́ло].

$4^{\circ}$ Безлична је конструкција и у 2691. стиху:

Помогосмо Петру Великоме, па сва наша крвца и страдања

Бӧгом прӧсто када смо помогли осветивши Петра од А̀хмета.

[ШМ 2689-2692],

али се у њој може алтернативно реконструисати оптатив помоћног глагола: прӧсто [би́ло], али и императив: [нѐка је] прӧсто. 
Ни у једном од наведених примјера није могуће васпоставити глаголску копулу [је].

(4) У фразеолошком подтипу д о б р о д о ш л и ц е оптатив је посвједочен и у једнини: Добро доша честити вӓлйсу! [ШМ 3698] и у множини мушког: Добро дошли браћо Црноेгорци: [ШМ 119]; Добро дошли браћо Црмнниа̄ни! [ШМ 2955] и (формално) женског рода: Добро дошле цуцке четовође! [ШМ 623]. Користи се и у подтипу здр а в и це, али за њих у спјеву нема примјера.

3.3. У Шћепану Малом издвајамо фразеолошки жанр (са два подтипа) 9. Ап отеозе [види даље т. (1)] и благодарења [види даље т. (2)].

(1) У фразеолошком подтипу ап о те оз е (похвале) користи се именица-предикат слӓва (без глаголске копуле у оптативној конструкцији), а употребљава се превасходно у односу на Господа Бога:

О Г̈осподи, слава твојој сили

и десници твојој свёмогӯћōj

[ШМ 1698-1699];

Слӓва Бӧгу што Турчин посрну;

нӧ прѐд кйм је, књаже, посрнуо?

[ШM 2741-2742].

Ова и оваква употреба именице слӓва настала је елипсом облика императива трећег лица једнине бйди [слава] < бжди [слава] у значењу ' [слава]', а посвједочена је у спјеву и на црквенославенском језику: Патрѝја̄px устаје нӓ ноге и чита »Слава въ вышнихъ Богу«. [ШМ +565].

Као обична именица, ван разматраног фразеолошког жанра, именица слӓва је употријебљена у бројним контекстима, на примјер: већ је слава наша погинула - / ка̀вурскй смо сада задушници. [ШМ 3630-3631], гдје она није предикат него субјекат.

Навешћемо још један примјер употребе именица слӓва: Ко ће ка̂ Бог (да му је за̀ славу!): [ШМ 1791]. Она је и овдје у оптативној конструкцији, али у њој није елидиран (аналитички) облик императива трећег лица једнине.

(2) У фразеолошком подтипу благодарења (захвале) користи се именица-предикат хва́ла (без глаголске копуле у оптативној конструкцији). Настала је на исти начин као и именица слава и у спјеву се и она користи у односу на Бога:

Боже драги, на свему ти хва́ла [ШМ 529];

Ми смо шака малѐна народа,

Богу хва́ла, ӧпйта свободом -

[ШМ 2746-2747]; 
на сва наша кумства нё обр̄ну, нити једном рече „хва́ла Бӧгу”, нӧ све прати ону наопаку.

[ШМ 3015-3017].

Као прелазну категорију између оптатива и предикатива посматрамо именице слӓва и хва́ла у предикативној функцији (без глаголске копуле у саставу одређеног фразеолошког жанра). О овим предикативним именицама види у Маројеви т 2020: 626.

3.4. У Шћепану Малом издвајамо и оптативни фразеолошки жанр 10. Кв а ли фикати в и, с четири предикатива у своме саставу као четири подтипа у оквиру жанра.

(1) Фразеолошки подтип квалификатива с додатном компонентом значења у п и т а н о с ти (недоумице) представљен је предикативом хва̂ла (обавезно у споју с именицом /дат./ Бӧгу), који је настао преображајем (и прозодијским и семантичким) именице-предиката хва́ла (без глаголске копуле у оптативној конструкцији) [види МАРОјЕвић 2020: 626].

Фразеологизам хваิла Бӧгу у Шћепану Малом има једну потврду: Хваิла Бӧгу несрећна чӧвјека, [ШМ 105].

У Речнику Његошева језика, у првом тому, у одредници борг, наводи се израз фала, х вала б о гу, у два значења: 1) богуза славу; на срећу; 2) узвични израз за дивљење, за чуђење [Стевановић и др. 1983 I: 40]. У другом тому, у одредници фа́ла, наводи се прилошки израз фала богу, у два значења: а. захваљујући богу; б. служи као исказ дивљења [Стевановић и др. 1983 II: 461], а у одредници хва́ла - фразеологизам [х в а́л а] б о г у, у два значења: 1) сложена узречица којом се изражава захвалност богу за нешто; 2) сложена речияа за исказивање чуђења и дивљењ а [Стеванови и др. 1983 II: 470].

Састављачи Речника Његошева језика, дакле (и то је прва наша замјерка), два различита израза, с различитом прозодијом и различитог значења, наводе као два значења једног истог фразеологизма: $1^{\circ}$ у изразу хва́ла Бӧгу именица хва́ла чува своје значење и граматичку природу, има нормалан дугоузлазни акценат, а може бити употријебљена и у постпозицији: Б̈огу хва́ла; $2^{\circ}$ у изразу хва̂ла (фа̂ла) Бӧгу, који је с једном потврдом посвједочен у Шћепану Малом и са четири у Горском вијенцу [види примјере у ширем контексту и коментар у МАројеви 2005: 701-703], именица хва́ла је адвербијализована, прешавши у предикатив као нову врсту ријечи, с побочним дугосилазним акцентом (који је могућ само у синтагми, овдје са компонентом Бӧгу), и не може бити употријебљена у постпозицији. Друго, први израз тумаче на три различита начина, а сва три су и непрецизна и нетачна. Треће, за други фразеологизам (код њих друго значење) наводе као примјер (нетачно га цитирајући) [С тввАнови и и др. 1983 II: 470, s. v. хва́ла] и овај из Огледала србског: Хвала Богу, хвала великоме, 
/ како Турци низ Стијену скачу; / што не скочи овђе низ Стијену, / то утече с Махмутом-везиром. (XXIX: Удар Махмут-паше на Пипере, 109-112), у коме је несумњиво посвједочен први фразеологизам, из чега погрешно изводе закључак да други израз служи (и) као исказ дивљења.

У текстолошким напоменама у Горском вијениу објаснили смо врсту ријечи и фразеолошку употребу, по обрасцу: хваิла (Бӧгу) - предикатив с поб. дугосил. акц.; хва̂ла Бӧгу - фраз. ‘збиља'. Сада додајемо: фраз. (жанр: квалификатив упитаности).

(2) У фразеолошком подтипу квалификатива с додатном компонентом значења благе в и е ст и употребљава се предикатив блӓго (мѐни), који има побочни краткосилазни акценат, па с обликом датива личне замјенице с главним акцентом формира сложену фонетску ријеч: Блӓго мѐни и роду србскоме, [ШМ 453]; Блӓго тѐби 'Ӓмзо-бӓрјакта̄ре, [ШМ 1037]; блӓго њѐму и његовој дуิши! [ШМ 3293]; Блӓго нӓма, наше сунце сјајно, [ШМ 310]; Блӓго вӓма до шест витезова̄ [ШМ 2481]; блӓго вӓма, сиви соколови, [ШМ 2490]; Блӓго вӓма тамо и овамо: [ШМ 3788]. Умјесто личне замјенице носилац главног акцента може бити именица, као (и у првом и у другом полустиху) пјесме у Прилогу, из које је узет мото спјева: блӓго рӧду а блӓго по̀то̄мству! [ПСР 42].

Предикатив се прозодијски разликује од хомонимичне именице, која има главни, дугосилазни акценат, на примјер: нй за једно блаิго на свије́ту. [ШМ $1150]$, као и од хомонимичног придјева и прилога.

(3) У фразеолошком подтипу квалификатива с додатном компонентом значења наговјештавања невоље употребљава се предикатив тёшко (тӧме̄), који има побочни краткосилазни акценат, па с обликом датива замјенице с главним акцентом формира сложену фонетску ријеч: Тёшко тӧме̄ ко о̀ вама брижи! [ШМ 2024]. Ако нека друга ријеч раздваја предикатив и датив замјенице, та друга ријеч је носилац главног акцента: тёшко ти га ӧнда̄ онијема / што ми силом пре́стол уграбише [ШМ 2338-2339]. Умјесто замјеничког може бити именички датив, али такви примјери у Шћепану Малом нису посвједочени.

Предикатив се прозодијски разликује од хомонимичног прилога, који има главни, дугосилазни акценат, а употребљава се у адвербијалној функцији: без мӱке̄ је ју̀накова̄т лӓко, / ма под круном од ӧлова - те̂шко. [ШМ 605-606] и у саставу предиката: Тёшко буде веома књазу Дӧлгорӱкову, [ШМ -2855]; Лӓко ли је што му дра̂го жељет, / ӓл' извр́шит - те̂шко и прётёшко, [ШМ 3876-3877].

(4) У фразеолошком подтипу квалификатива с додатном компонентом значења наговјештавања жал о с т и употребљава се предикатив кӱку (тӧме̄), кӱку (Ја̂нко), који има побочни краткосилазни акценат, па с обликом датива замјенице или вокатива именице, који имају главни акценат, формира сложену фонетску ријеч: Кӱку тӧме̄ од кога сте јачи - [ШМ 1133]; „Кӱку Ја̂нко, горски змају, / с тобом пада наша слава!” [ШМ 2046 (50)]. 
Предикатив се прозодијски разликује од хомонимичног узвика, који има главни акценат и послијеакценатску дужину (кйкӯ!) и употребљава се изван реченице, али такви примјери у спјеву нису посвједочени.

\section{4. ФРАЗЕОЛОШКЕ СТИЛСКЕ ФИГУРЕ}

4.1. Међу стилским фугурама које се налазе у процесу фразеологизације на првом мјесту треба издвојити фразеолошки жанр 11. Хе н д и а д и с.

Хендиадис је у Шћепану Малом заступљен бројним примјерима (и бројним типовима). Другом, формалносинтаксички истоврсном компонентом наглашава се значење прве, тако да је овај фразеолошки жанр важно експресивно средство интензификације. Компоненте хендиадиса нису самостални истоврсни чланови реченице. Јединствено значење условљава и интонационо јединство, па то утиче на опкорачење цезуре или на опкорачење границе између другог и трећег такта.

(1) Посебан тип је хендиадис комплементарног карактера, као што је израз тамо и овамо у значењу 'свуда': иду наше чете и њихове / свим ћена́ром тамо и овамо, [ШМ 3736-3737].

(2) Исти израз може бити хендиадис, као што је израз тамо и овамо у значењу 'свуда' [види горе т. (1)], и копулативна синтагма која није хендиадис, као што је истовјетни израз у 3788. стиху:

$$
\begin{aligned}
& \text { Блӓго вӓма тамо и овамо: } \\
& \text { овамо сте у̀ њедра па̀диши, } \\
& \text { а у нашој дивној танда̀рихи } \\
& \text { сјѐђећете за пуним софрама } \\
& \text { уз кољено турскоме Ӓлла̄ху } \\
& \text { и његову дра̂го̄ме Пророку - }
\end{aligned}
$$

[ШМ 3788-3793].

Разлика није само у значењу него и у интонацији (и версификацији): у копулативној синтагми која представља хендиадис компоненте се изговарају као једна интонациона цјелина, па се, у наведеном примјеру, остварује опкорачење границе између другог и трећег такта.

(3) Хендиадис као стилска фигура и фразеолошки жанр најближи је жанру сталних епитета. Разлика је у томе што је основни, класични тип сталних епитета оформљен као веза конгруентног атрибута као зависног с именицом као управним чланом синтагме, тј. компоненте му се налазе у односу субординације, док се основни тип хендиадиса остварује везом двију ријечй, најчешће именица, које се налазе у независном односу, односу координације. Транспозицијом један жанр прелази у други. Тако хендиадис кита и сватови, 
који наводи Лука Зима [ZІма 1880 (1988): 255] (и понављају српски стилистичари), има као свој синоним израз кићени сватови, који је транспозицијом прешао у стални епитет.

4.2. Међу стилским фигурама које се налазе у процесу фразеологизације на другом мјесту издвајамо фразеолошки жанр 12. Пе р и фр аз а. Перифраза као стилска фигура и фразеолошки жанр представља важну и веома сложену семантичку структуру пјесничког језика Његошевог.

(1) У Шћепану Малом су потврђени пе ри фр астички преди кати, класичне перифразе књишког језика. Такав је фразеологизам обра́тити nӧглёде (перифраза у значењу 'погледати'): куд год човјек обрати погледе - [ШМ 3357], који налазимо и у Лучи микрокозма: Ӓх Сата̀но, обра́ти пӧгле̄де - [ЛM 1238 (IV 28)].

(2) Перифразе типа име чега омиљено су стилско средство Његошево у „малом дјелцу”, како је Лучу микрокозма пјесник назвао у писму Сарајлији.

И у Шћепану Малом среће се овај тип перифразе. Перифраза ӥме ср̈бско̄: за свободу и за име ср̈бско̄ [ШМ 1689] има значење '(за) Србе, (за) Србство’, а дйчно̄ ӥме свободде̄: и свободе дично име / гадном ногом да зама̀ра̄. [ШМ 2142 (70)] - значење '(ак.) дичну свободу'.

За прву перифразу као интертекстуалну паралелу наводимо перифразу йме Сёбӑ из Луче микрокозма: богомрске Србства отпаднике: / злоћа њима мрачи име Срба - [ЛМ 198-199 (Пролог)] у значењу /ак./ 'Србина', тј. Србство). Облик једнине (ген.) Сёба има значење множине и кореспондира с колективним етнонимом (који би код Његоша гласио: Србство) и с адјектонимом (код Његоша: србски).

Појављују се и примјери декомпоновања фразеологизма. У стиху: име би им давно погинуло [ШМ 3611] перифраза (ак.) ӥме [црногорско] значи 'биће [црногорско]'.

(3) Перифразе типа драго је некоме значе 'неко хоће', на примјер: јер вјерују што је њима дра̂го, / а не оно што је другом дра̂го; [ШМ 1474-1475]. Овдје се предикативни прилог дра̂го прозодијски разликује од истог тог прилога у нефразеолошкој употреби (у реченицама типа Мени је дра́zо што...), али ипак не прераста у предикатив него има прелазни карактер (глаголска копула је обавезна компонента израза).

4.3. Међу стилским фигурама које се налазе у процесу фразеологизације на трећем мјесту издвајамо фразеолошки жанр 13. Таутолошки и з раз. Таутолошки изрази као стилска фигура сродни су с хендиадисом као стилском фигуром и фразеолошким жанром, па се могу сматрати подврстом хендиадиса. 
(1) Први тип таутолошких фразеолошких израза састоји се од двије компоненте које припадају различитим врстама ријечи. Класични таутолошки изрази су у форми синтагме глагола и именице у зависном падежу истог коријена с међусобном творбено-семантичком везом. Такав је таутолошки израз штимтом штиитйш (веза истокоријенског глагола у другом лицу једнине презента и именице у инструменталу у значењу средства помоћу којег се глаголска радња врши): кога штитиш штитом Боже / дајући му ти свободу? [ШМ 2034 (38)]. Исти такав израз налазимо у пјесми „У врстама таинственим...” (из Биљежнице), само што је глагол у трећем лицу једнине: нек Вас рука свемогућа / својим штитом свагда штити - [У врстама 11].

(2) У другом типу таутолошких фразеолошких израза понавља се иста ријеч, али у различитој граматичкој конструкцији. Такав је примјер из Шћепана Малог: Не може се никад исписати / ка̂ из у́ста̄ у у́ста предати: [ШМ 2295-2296], који ћемо довести у везу с примјером из Ноћи скупље вијека: Не мичу се уста с уста̄ [су́ста̄̄

(3) Трећи тип таутолошких фразеолошких израза састоји се од двије исте ријечи, али се друга модификује префиксоидом: молитве су добре и прёдо̀бре, [ШМ 3461], који се може трансформисати у обични префикс: ӓл' извр́шит - те̂шко и прёте̄шко, [ШМ 3877]. Префиксоид односно префикс интензивира значење придјева односно прилога.

4.4. Мада он спада у својеврсну таутолошку конструкцију, издвојили смо и засебно описујемо фразеолошки жанр 14. Су перл ат и в н и и з раз.

Суперлативни изрази су фразеологизми који имају својеврсну синтаксичку структуру - то су таутолошки изрази у којима је иста именица у одговарајућем падежу једнине комбинована са својим инструменталом или генитивом множине. Његош ове фразеологизме различито оформљује у разним дјелима.

(1) У Шћепану Малом друга компонента је у инструменталу множине с предлогом над, што је стандардни облик и у књижевном језику: па̀диша си и цар над царима [ШМ 1069]; ја, император над императорима, [ШМ -1614].

(2) У Горском вијениу друга компонента је у генитиву множине с предлогом од, што је дијалекатска конструкција: цар од цара̄ мене је спремио [ГВ 1081].

(3) У Лучи микрокозма посвједочена су три суперлативна израза [MАројеви п 2016: 416-417], два у значењу 'свијет над свјетовима', од којих је први исказан домаћом лексемом: вёћ трёпе̄том $\|$ свејеет свјёто̄ва̄ $\overline{\mathrm{x}}^{\mathrm{x}} \mid$ глёда̄х [ЛМ 429 (I 229)], а други русизмом: мйр мйро̄ва̄ $\overline{\mathrm{x}}^{\mathbf{1}} \mid$ бјёше | на̀пунио [ЛМ 439 (I 239)], док је трећи у значењу 'престо над престолима': Над вйсокйм \| пре́столом | преิсто̄ла̄ $\overline{\mathrm{x}}^{\mathrm{x}}$ [ЛМ 691 (II 141)]. Ови Његошеви изрази прављени су по руском структурно-семантичком моделу типа Песня песней 'Пјесма над пјесмама'. 
НАПомене.

1. У пјесми Поздрав србском роду у Прилогу посвједочен је таутолошки израз с другом компонентом у генитиву једнине: живот, душа душе благо̀роднё, [ПСР 23], али он није суперлативног значења.

2. Специфичан је суперлативни фразеологизам вла̀далица ви́л $\bar{a}^{x}$ у значењу 'вила над вилама' у пјесми Ноћ скупља вијека - друга компонента је у генитиву множине без предлога, али он није оформљен као таутолошки израз: јошт се

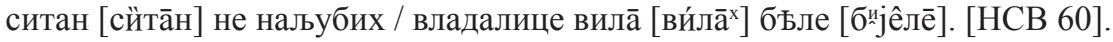

\section{5. ЗАКЉУЧАК}

5.1. Док су у првом Његошевом спјеву, у Лучи микрокозма, поред фразеолошких јединица српског народног, примарно фолклорног поријекла, заступљени крилати изрази (фразеологизми чији се извор може историјски документовати), славенизми (фразеолошки изрази из старе словенске књижевне традиције, старославенске и староруске), русизми (фразеолошке јединице које је пјесник позајмио из руског језика и књижевности) и оказионализми (Његошеви ауторски фразеологизми), па је испреплетаност општејезичких (и општекултурних) и ауторских (оказионалних) фразеологизама те домаћих израза и русизама основна карактеристика идиоматике спјева [види МАР о Еви $2016^{6}$; уп. и МАро вви и $2016^{\mathrm{B}}$ ], фразеологија Шћепана Малог је превасходно фолклорног поријекла, али је обогаћена пјесниковим индивидуалним стилским, семантичким и синтаксичким ефектима.

5.2. У погледу фразеолошких жанрова, фразеологија Шћепана Малог много је ближа фразеологији другог Његошевог спјева, Горског вијениа, коју је монографски описала Ана Пејановић [ПЕЈАнови 2010], али је знатно богатија, и разуђенија, што је условљено тематиком дјела и богатијим пјесничким искуством.

5.3. На грађи Шћепана Малог могуће је дати не само ширу, и потпунију, класификацију фразеолоших жанрова у српском језику него и понудити њихову систематизацију, што смо ми у овом раду и учинили.

$1^{\circ}$ Фразеологизме у ужем смислу, сталне епитете, устаљена поређења и идиоме, означили смо као синтагматске фразеолошке жанрове јер се остварују формално на нивоу синтагме, а стварно чине овај или онај члан реченице.

$2^{\circ}$ Фразеологизме у ширем смислу, пословице, изреке и узречице, сврстали смо у реченичке фразеолошке жанрове јер се они остварити, или се могу остварити, на нивоу реченице.

$3^{\circ}$ Оптативни фразеологизми [види т. 5.4] имају у суштини полупредикативну функцију, тј. указују на неку допунску информацију или поруку. 
$4^{\circ}$ У четврту групу сврстали смо структуре које се налазе у процесу фразеологизације и имају одлике стилских фигура.

5.4. У оптативне фразеологизме сврстали смо оне изразе који су не само генетски везани за некадашњи императив трећег лица једнине у оптативном значењу него се и остварују помоћу иновација у структури врста ријечи.

$1^{\circ}$ Основни тип заклетви остварује се помоћу предикатива тӓко, али се, за разлику од квалификатива, предикатив може и елидирати или замијенити оптативом (обавезно с негацијом).

$2^{\circ}$ Клетве, благослови, добродошлице, опраштања и здравице изражавају се оптативима (по правилу, без негације) као једној од двије нове врсте ријечи у српском језику. (Клетве с негацијом типа Бог те не убио имају статус клетве с помиловањем.)

$3^{\circ}$ Апотеоза и благодарење остварују се помоћу предикативних именица слӓва односно хва́ла (без глаголске копуле у оптативној конструкцији), а те именице представљају прелазну категорију између оптатива и предикатива.

$4^{\circ}$ Четири подтипа фразеолошког жанра квалификатива (с додатном компонентом значења упитаности или недоумице, благе вијести, невоље и жалости) изражавају се помоћу предикатива као друге од двије нове врсте ријечи у српском језику, при чему се, за разлику од заклетви, предикатив не може елидирати.

\section{ЛИТЕРАТУРА}

ГВ: Горски вијенаи [у књ. Маројевић 2005: 35-222].

Зима 1880 (1988): Luka Zima, Figure u našem narodnom pjesništvu: S njihovom teorijom, Zagreb: Globus, 1988. [Pretisak izd. JAZU iz 1880].

Караџић 1836: Народне српске пословице и друге различне, као оне у обичај узете ријечи, Издао их Вук Стеф. Караџић, на Цетињу, 1836.

Караџић 1849: Српске народне пословице и друге различне као оне у обичај узете ријечи. Издао их Вук Стеф. Караџић. у Бечу, 1849.

Костић Д. 1902: Лажни иар Шћепан Мали: Историческо збитије осамнаестога вијека. Од Петра Петровића Његоша. [Предговор написао Јаша М. Продановић. Приредио Драгутин Костић] Београд-Загреб: Штампарија Мила Маравића, 1902. (Српска књижевна задруга, 63). [Првом пагинацијом штампани су, накнадно, предговор и биљешка о издању потписана са С. К. 3.].

Костић Л. 2000: Лазо М. Костић, Његош и српство, Сабрана дела, Четврти том. Београд: ЗИПС, Српска радикална странка. 
Лазаревић 2011: Лаза К. Лазаревић, Приповетке, Треће изд., Београд: Evro-Giunti 2011.

ЛМ: Луча микрокозма [у књ. Маројевић 2016аa : 105-224 (критичко издање), 903-1020 (акценатско издање)].

Маројевић 2005: Петар II Петровић-Његош, Горски вијенаи, Критичко издање. Текстологија, Редакција и коментар Радмило Маројевић, Подгорица: ЦИД.

Маројевић 2016“: Петар II Петровић-Његош, Луча микрокозма, Критичко издање. Текстологија, Редакција и коментар Радмило Маројевић, Подгорица: ЦИД - Цетиње: Narodni muzej Crne Gore.

Маројевић 2016 ${ }^{\text {: }}$ Радмило Маројевић, Фразеолошка реконструкција у Лучи микрокозма, Српски језик, XXI, 5-23.

Маројевић 2016 : Радмило Маројевић, Експресивност у Лучи микрокозма: (фразеолошки аспект), Научни састанак слависта у Вукове дане, $45 / 1,125-139$.

Маројевић 2017: Петар II Петровић-Његош, Биљежница. Критичко издање. Текстологија, Редакција и коментар Радмило Маројевић, Подгорица: ЦИД.

Маројевић 2018: Петар II Петровић-Његош, Луча микрокозма. Горски вијенаи. Шћепан Мали, Основно издање. Ортографија и ортоепија, Редакција и коментар Радмило Маројевић, Никшић: Будимљанско-никшићка епархија - Београд: Друштво за неговање Његошевог дела.

Маројевић 2020: Петар II Петровић-Његош, Шћепан Мали. Критичко издање. Текстологија, Редакција и коментар Радмило Маројевић, Подгорица: ЦИД - Цетиње: Narodni muzej Crne Gore.

НСВ: Ноћ скупља вијека [у књ. Маројевић 2017: 347-363].

Пејановић 2010: Ана Пејановић, Фразеологија Горског вијенща: Фразеолошки жанрови. Културни конщепти. Руски преводи, Подгорица: ЦАНУ.

Пејановић 2015: Ана Пејановић, Синтакса, семантика и лингвокултурологија компаративних фразеологизама, Бања Лука: Апеирон.

ПСР: Поздрав (србском) роду [у књ. Маројевић 2018: 450-452].

Стевановић и др. 1983 I: Речник језика Петра II Петровића Његоша, [На корицама: Речник Његошева језика], Израдили Михаило Стевановић и сарадници Милица Вујанић, Милан Одавић и Милосав 
Тешић, Уредник Михаило Стевановић, Књ. I, Београд: Српска књижевна задруга и др.

Стевановић и др. 1983 II: Речник језика Петра II Петровића Његоша, [На корицама: Речник Његошева језика], Израдили Михаило Стевановић и сарадници Милица Вујанић, Милан Одавић и Милосав Тешић, Уредник Михаило Стевановић, Књ. II, Београд: Српска књижевна задруга и др.

У врстама: „У врстама таинственим...” [у књ. Маројевић 2017: 364-366].

ШМ: Шћепан Мали [у књ. Маројевић 2018: 289-449].

\section{ФРАЗЕОЛОГИЧЕСКАЯ РЕКОНСТРУКЦИЯ В ПОЭМЕ «ЩЕПАН МАЛЫЙ» ПЕТРА НЕГОША}

\section{Резюме}

В настоящей работе представлена классификация фразеологических единиц в поэме «Щепан Малый» сербского поэта Петра Негоша с точки зрения их жанров.

Постоянные эпитеты, устойчивые сравнения и идиомы представляют собой группу фразеологизмов на уровне словосочетания. - В группу фразеологизмов на уровне предложения входят пословицы, поговорки и присловья. - Оптативные фразеологизмы оформлены с помощью двух-трех инноваций в системе частей речи сербского языка (оптативов, предикативов и предикативных существительных в качестве переходной категории). - Гендиадис, перифраза, тавтологические и суперлативные выражения составляют группу фразеологических стилистических фигур.

Просодическому и интонационному анализу стиха поэмы «Щепан Малый» посвящен раздел «Стиховедческая реконструкция» в научном издании произведения (под ред. Р. Н. Мароевича, Подгорица-Цетинье, 2020).

Ключевые слова: Петр Негош, поэма «Щепан Малый», фразеологические жанры, фразеологизмы-словосочетания, фразеологизмы-предложения, оптативные фразеологизмы, фразеологические стилистические фигуры. 